\title{
The Black-tipped Leafhopper, Bothrogonia ferruginea \\ Auct., of Japan and Formosa
}

\author{
By Tamotsu Ishinara
}

College of Agriculture, Ehime University, Matsuyama, Japan.

\section{INTRODUCTION}

In Japan the black-tipped leafhopper (Japanese name: Tsumaguro-ôyokobai) is known as an injurious species to the pear tree, the mulberry tree, the tea shrub, various berries, the sugarcane, etc. Since UHLER (1896) identified the Japanese specimen with Tettigonia ferruginea (FABRICIUS, 1794), the specific name has been adopted by many authors to the Japanese and to the Formosan specimens, and therefore Bothrogonia ferruginea (FABRICIUS) has been considered a species distributed widely from Japan to the Oriental countries, further to South Africa.

Recently the author has examined the Japanese and Formosan specimens and found that they are entirely different from the $B$. ferruginea (FABRICIUS), the type-locality of which

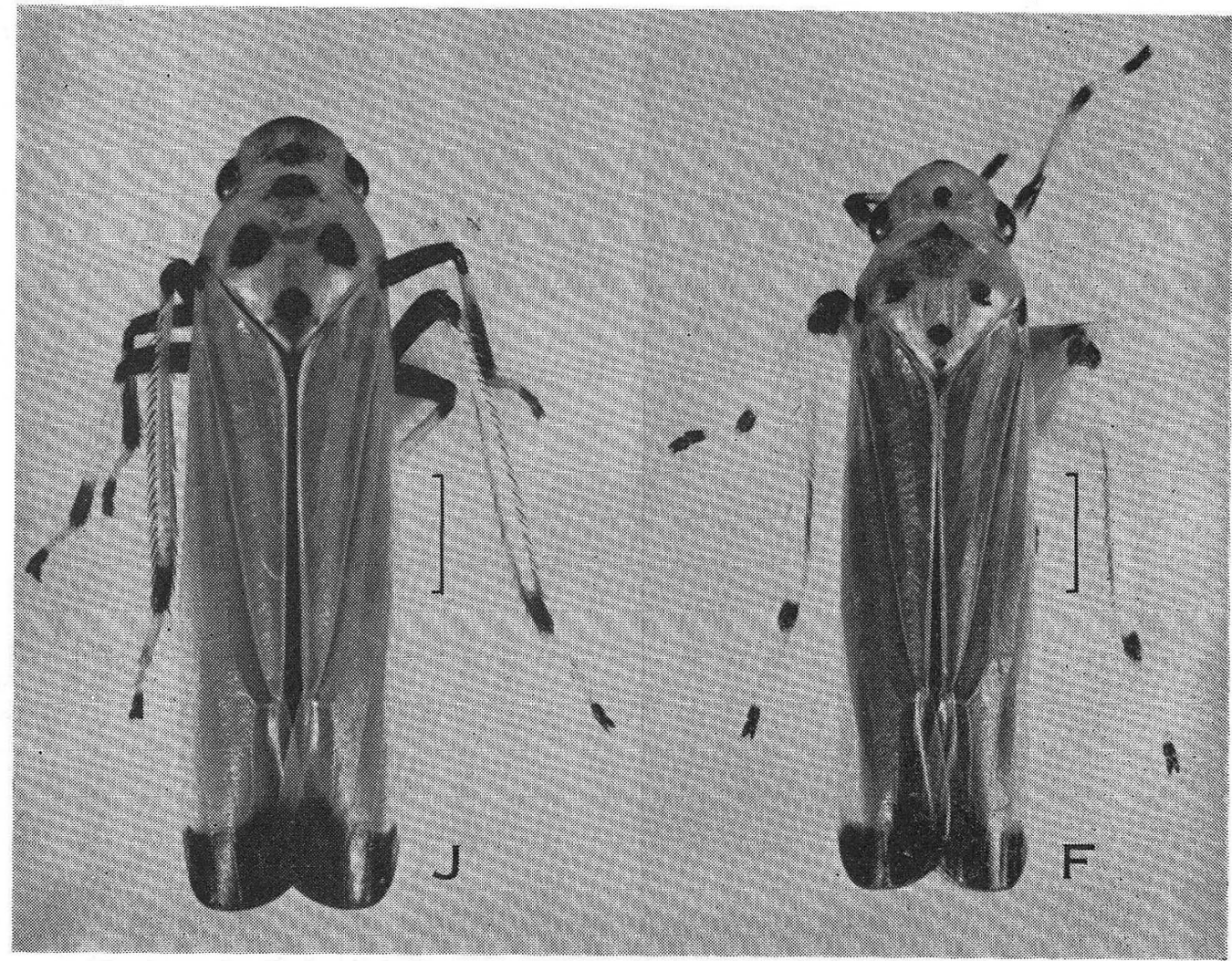

Fig. 1. J, Bothrogonia japonica sp. nov. $\sigma^{7}$

F, B. formosana (Niatsumura) o'

(Received for publication, October, 22, 1962) 
is Cape of Good Hope, S. Africa. It was concluded that the Japanes species is an undescribed one and the Formosan species seems B. formosana (MATsumurA, 1912).

The author wishes to thank Prof. T. SHIROzU of Kyushu University for his kind contribution by sending many valuable specimens of Formosan Homoptera, which gave the author a chance to make the present report.

Bathroogonia japorica sp. nov. [Figs. 1-2 : J] Japanese name: Tsumaguro-ôyokobai Tettigonia ferruginea (nec FABRICIUS, 1794), UHLER, 1896: p. 293 ; ISHIHARA, 1953 : p. 16 (Megalotettigella); IsHIHARA, 1954 : p. 12 (Bothrogonia); EsAKI et Iто, 1954: p. 8 (Amblycephalus, synonymy).

Length about $13 \mathrm{~mm}$ (till tegminal apices), about $11 \mathrm{~mm}$ (excluding tegmina). Body orange- yellow (when alive, fresh green), with black markings as follows: one small marking at apex of vertex, one roundish marking placed almost contiguous with pronotum, one rectangular marking near the anterior margin of pronotum, a pair of roundish markings of pronotum placed contiguous with the posterior margin and one central roundish marking of scutellum. Apex of scutellum also infuscated. Head in the frontal view mostly orange-yellow except the following black portions: nearly distal half of frons a little inferior to the middle, a wide medio-longitudinal stripe (which is visible dorsally as a black marking at apex of. vertex) of frons and clypeus except for infero-lateral portions. Tegmina concolorous with body except a small portion at base of each tegmen which is black and apical areas which are contrastingly black. Femora throughout all

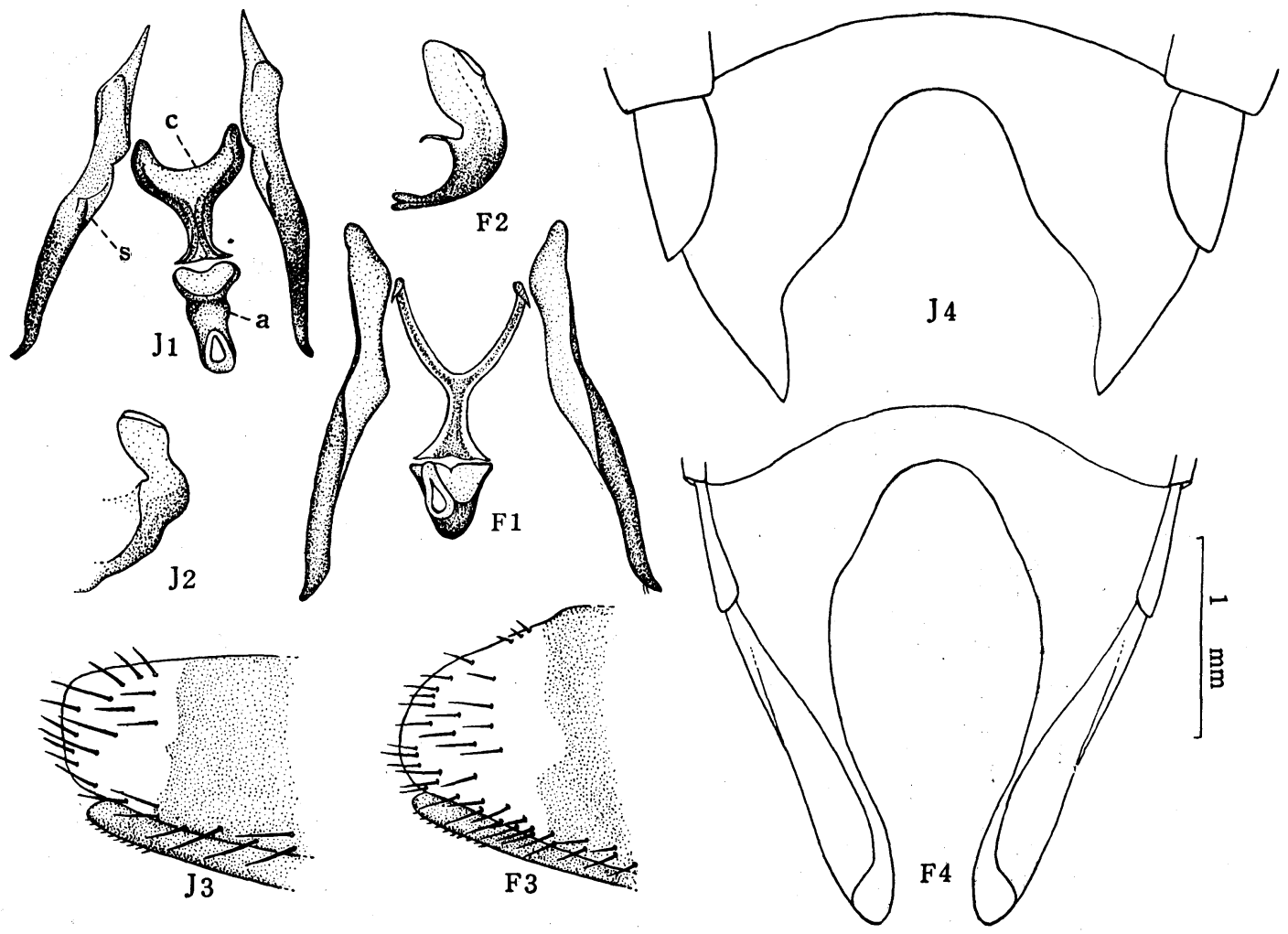

Fig. 2. J, Bothrogonia japonica sp. nov.

F, B. formosana (MATsUmura)

1, Dorsal view of whole internal genitalia of the male; 2, Lateral view of aedeagus; 3 , Lateral view of the apex of the female eighth sternite; 4, Ventral view of the female seventh sternite. a, aedeagus; $c$, connective; s, style. 
Tegs black. Tibiae mostly pale yellowish, with bases and apices which are black, distal half of anterior tibia conspicuously infuscated. Tarsi pale yellowish, with black apices. Claws black. Body beneath black, with a bluish lustre. Female eighth sternite with yellowish apex [Fig. 2: J 3].

Connective thickened and short. Styles acutely pointed at base, with apices which are blunt and slightly curved outward. Aedeagus angularly curved dorsad, somewhat constricted about -the middle, without any process [Fig. 2: J 1 -2]. Female seventh sternite in the ventral view shallowly and roundly incised anterior, with both sides sharply pointed caudad, eighth sternite in the lateral view subtruncated, with spines comparatively small in number, of which ventral series is rather uniseriate along ovipositor [Fig. 2: J 3].

Specimens examined: holotype $(\hat{\sigma})$ and allotopotype (우) collected in Mt. Sara near Matsuyama, Shikoku, IX-23, 1954 by T. IsHIHARA ; 23 paratypes (소오우우) collected in and around Matsuyama, Shikoku, by T. IshinARA et al. All the specimens now in the author's hand were collected in Shikoku, however the author had also collected not a few specimens in Honshu . and in Kyushu.
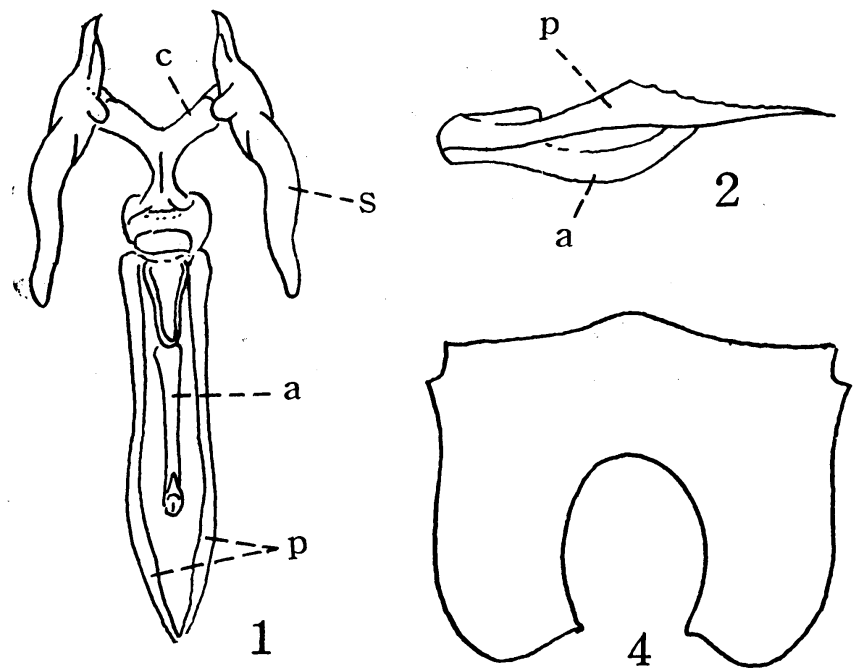

Fig. 3. Bothrogonia ferruginea (FABRICIUS)

The numbers and letters are explained in Figure 2, except $p$ which designates the process of aedeagus. u[from S. R. CAPCO, 1959]
Distribution: Japan (Honshu, Shikoku and Kyusyu).

The present new species entirely differs from known species of the genus in the internal characters of the male genitalia and the seventh and eighth sternites of the female. The characteristics of $B$. ferruginea (FABRICIUS) with which the Japanese specimen identified are fundamentally different from those of the present species [Fig. 3].

In Japan, this species injures various cultivated plants as above-mentioned. The imago appears once a year, at the beginning of September and hibernates among bushes in the same stage.

\section{Bothrogonia formosana (MATSUMURA,} 1912) [Figs. 1-2: F]

Japanese name: Taiwan-tsumaguro-ôyokobai

Tettigonia formosana MATsumura, 1912: p. 34 (1우, Gyochi bei Horisha); EsaKI et ITo, 1954 : p. 12 (Amblycephalus, cat.).

Although the size and coloration are similar to the previous species, the body is slightly slenderer and the black markings or black portions of head and thorax are usually less developed.

Black roundish markings on vertex, pronotum and on scutellum small. Head in the frontal view with a black marking usually recognizable only at base of frons and both basal sides of clypeus which are black. Femora and tibiae throughout all legs pale yellowish except basal and distal portions, whic are black, anterior tibia apically infuscated only in one-fifth.

Connective conspicuously slender, with a small reflection at each base. Styles similar to those of previous species except bases which are clearly rounded. Aedeagus with bluntly pointed apex, somewhat weak constriction and a small basal arm. Female seventh sternite in the ventral view so deeply incised that both sides long developed caudad, with apices not pointed but rounded, eighth sternite rounded, with spines comparatively large in number, the series along 
ovipositor not uniseriate.

Specimens examined: $1 \hat{\delta}$, Nanzankei, Formosa, VI-24, 1961; 4소오우우, RimoganMagan, Formosa, VII-10, 1961; 1우, UraiAgyoku, Formosa, VII-11, 1961. All collected by T. SHIRozu.

Distribution: Formosa.

The species of Genus Bothrogonia are known to have so extensive variation in the coloration of vertex, pronotum or of tegmina as DisTANT reported six varieties in $B$. ferruginea (FABRIcIUS) (DIstANT, 1908) and they are very similar in appearance so that a critical study of the genitalia is essential to separating them to species (CAPCO, 1959). The Prof. Matsumura's type specimen of the present species is a single female which seems to have an aberrant coloration. Judging by the Matsumura's description, "Letztes Bauchsegment in der Mitte deutlich tiefer ausgebuchtet als bei $T$. ferruginea, so- dass seitlichen Vorragungen viel länger und spitziger erscheinen", and variable coloration in the genus besides, the author decided to identify the Formosan specimen with the present species.

\section{LITERATURE CITED}

CaPco, S. R. (1959) Phlip. J. Sci. 87 (2) : 159 167. Distant, W. L. (1908) Faun. Brit. Ind., Rhynch. 4, $501 \mathrm{pp}$.

EsAKI, T. and S. ITo (1954) A tentative catalogue of Jassoidea of Japan and her adjacent territories, $315 \mathrm{pp}$.

IsHiHARA, T. (1953) Sci. Rep. Matsuyama Agr. Coll., $11: 1 \sim 72$.

(1912) ibid. $14: 1 \sim 28$.

Matsumura, S. (1912) Annot. Zool. Jap., 8 (1) $: 15$ $\sim 51$.

Uhler, P. R. (1896) Proc. U. S. Mus., 19 : 255 297.

\section{摘要 \\ 日本および台湾産のいわゆるツマグロオオョコバイについて \\ 石原保 \\ 愛媛大学農学部}

ナシ,クワ,チャ,種々の漿果類,サトウキビなどを加害 する多食性の害虫として, 本邦でよく知られているッマ グロオオヨコパイは,てれまで Bothrogonia ferruginea (FABRICIUS) の学名が用いられ, 本州以南東洋熱帯地方, 更にアフリカにかけて広い分布をする種とされてきた。

今回, 日本産と台湾産の標本を研究したととろ, いず れもそれとは縁の近くない別種で, 日本産のものは新種 とすべきものであり, 台湾産のものも日本産にきわめて 近縁ではあるが,明らかに別種であるととがわかった。し たがって Bothrogonia ferruginea (FABRICIUS) は日本
列島には分布せず，日本産には Bothrogonia japonica ISHIHARA, 台湾産には, 色彩の異常な個体を夕イブスぺ シメンとしたものであるが, Bothrogonia formosana (MATSUMURA)を当てるべきととを明らかにした。なお， 和名は, 日本産にはツマグロオオヨコバイをてれまでど おり用いるべきであるが，台湾産には原記載に示されて いるホソッマグロオオヨコハイより, 種小名に準拠して タイワンツマグロオオヨコバイと呼ぶほうが妥当と思い 改称した。 